\title{
Personhood, Equality, and a Possible Justification for Criminal Punishment
}

\author{
Liat Levanon
}

\section{(I) Introduction}

Criminal punishment involves the use of aggressive force by the state. But why should the state be allowed - indeed, obliged - to deploy violence against its citizens in response to wrongdoing? This question has relentlessly troubled criminal lawyers and philosophers alike. The article presents an attempt to provide a satisfactory answer to this question.

The article assumes punishment to be an intentional imposition of deprivation or pain on Wrongdoer by an authority, in response to wrongdoing for which Wrongdoer has been determined to be in some way responsible. ${ }^{1}$ It discusses state punishment and focuses on its justifiability. Exploration of other questions regarding punishment, such as its legitimate form and its exact scope, is left for future research. ${ }^{2}$ However, all questions concerning punishment, and their resolutions, are intertwined. For example,

I would like to thank Andrew Botterell, whose thorough reading and insightful comments have significantly improved previous versions of this article. I would also like to thank Victor Tadros and the participants of the departmental seminar at the School of Law, Warwick University. Kai Ambos and Andreas Dimopoulos have read previous drafts and contributed to the development of my ideas in comments and discussions.

${ }^{1}$ The most famous and widely acceptable definition is the Flew-Benn-Hart definition, slightly different variants of which appear in Anthony Flew, "The Justification of Punishment” (1954) 29 Philosophy 291; in SI Benn, “An Approach to the Problem of Punishment” (1958) 33 Philosophy 331; in HLA Hart, "Prolegomenon to the Principles of Punishment” (1959-60) 60 Proceedings of the Aristotelian Society 1. [Hart]. For a discussion of this definition, see Thomas McPherson, "Punishment: Definition and Justification” (1967) 28 Analysis 21; Don E Scheid, "Note on Defining 'Punishment'” (1980) 10 Can J Phil 453, and the references there. See also John Kleinig, Punishment and Desert (The Hague: Martinus Nijhoff, 1973) at ch 2. ${ }^{2}$ A full philosophical account of criminal punishment would address several subordinate issues: What is punishment? Are there different types of punishment? Can the imposition of punishment ever be justified? Is there ever a duty to impose punishment? What forms and amounts of punishment can be legitimately imposed? HLA Hart has famously suggested a distinction between the general justifying aim of a system of punishment and the justification for any particular distribution of punishment. HLA Hart, Punishment and Responsibility (Oxford: Oxford University Press, 1968) at 1-27. 
the form and scope of punishment are determined, at least to some extent, by the justification for punishment (as well as,- of course, the characteristics of the enforcing authority). Accordingly, while discussing justification for punishment, this article hints at the potential ramifications for other issues.

The proposed argument is made in the context of deontological justifications for criminal punishment. Deontological justifications are based on the concepts of duties and rights. Deontological accounts may be contrasted with consequential accounts, but not necessarily with all types of teleological accounts. A theory that justifies a practice as right-vindication is deontological; it may also, perhaps, be teleological in some weak and peripheral sense (as it seeks to redress the violation); ${ }^{3}$ but it is by no means consequential. ${ }^{4}$ In such a theory, the justification for the practice is drawn by looking backwards at the right-violation and upwards at universal justice, rather than by looking forward into the contingent phenomenological needs of victims or other members of society. ${ }^{5}$

The article attempts to explain punishment as a practice that restores equality of infinite human value between the victim and the offender. Deontological accounts of criminal punishment have taken many different directions. ${ }^{6}$ To provide the necessary

${ }^{3}$ Though not necessarily so. Deontological accounts seek to restore justice; teleological ones seek to realize values because they are good as such, rather than because they were unjustly violated.

${ }^{4}$ And see in this regard Derek Parfit's accounts of Telic and Deontic equality, none of which is consequential in any way: Derek Parfit, "Equality and Priority" (1997) 10 Ratio 202. [Parfit]. See also Alan Brudner, Punishment and Freedom: A Liberal Theory of Criminal Justice (Oxford and New York: Oxford University Press, 2009) at 51. [Brudner]. Brudner describes his theory as teleological in one sense and deontological in another, but not consequentialist.

${ }^{5}$ Since the proposed justification for punishment relies on a right for equality that has been violated, reestablishment of equality through the imposition of punishment cannot be understood as a consequence in the philosophical sense. Reestablishment of equality is the fulfilment of a universal duty. In the same manner, retributivisim cannot be understood as a consequential doctrine even though it does require some contingent or otherwise independent effects such as suffering and reestablishment of a moral balance.

${ }^{6}$ For a review, see Leo Zeibert, Punishment and Retribution (Aldershot: Ashgate, 2006) especially at ch 4. See also John Cottingham, "Varieties of Retribution" (1979) 29 Phil Quarterly 238. One seminal work that I do not analyze here is Michael S Moore's account in Placing Blame: A Theory of Criminal Law (New York: Oxford University Press, 2010) at Part I, s III. For a discussion of Moore's theory see, e.g., David Dolinko, "Some Thoughts about Retributivism" (1991) 101 Ethics 537 at 55559. [Dolinko]. Another important work is Jean Hampton, “The Moral Education Theory of Punishment” (1984) 13 Phil \& Pub Affairs 208. 
background for my argument, I would like to draw special attention to Immanuel Kant's account of punishment in The Metaphysics of Morals, ${ }^{7}$ to Arthur Ripstein's more recent interpretation of Kant in his Equality, Responsibility, and the $\mathrm{Law}^{8}{ }^{8}$ and to Alan Brudner's Hegelian concept of punishment in Punishment and Freedom. ${ }^{9}$

Kant's account of criminal punishment is found mainly, though not only, in his Metaphysical Elements of Justice (Der Rechtslehre). ${ }^{10}$ While Kant's comments are not easy to integrate into a full and coherent account, some issues are clear enough. For Kant, crime endangers the commonwealth or the rightful condition. ${ }^{11}$ The rightful condition is justified by the universal law, and so is punishment. Kant explains that "[t]he law concerning punishment is a categorical imperative"; ${ }^{12}$ and later, with respect to the death penalty, he writes: "This is what [legal] justice as the Idea of the judicial authority wills in accordance with universal laws that are grounded $a$ priori". ${ }^{13}$ Thus, in the rightful condition, universal law directly justifies punishment, and, for Kant, such justification is simple and straightforward. Kant's oft-quoted account of state punishment is that "judicial punishment can never be used merely as a means to promote some other good for the criminal himself or for civil society, but instead it must in all cases be imposed on him only on the ground that he has committed a crime". ${ }^{14}$ Punishment is the application of Wrongdoer's hypothetical imperative to herself; it is the actualization of the procedure of universalization in its effects on Wrongdoer. ${ }^{15}$

Yet Kant does not clearly articulate the justification for such practical application of Wrongdoer's hypothetical imperative. ${ }^{16}$ Presumably, the application of Wrongdoer's imperative restores the rightful condition. However, Kant does not explain exactly

7 Immanuel Kant, The Metaphysics of Morals, ed by Mary Gregor with Introduction by Roger J Sullivan (Cambridge: Cambridge University Press, 1996).

${ }^{8}$ Arthur Ripstein, Equality, Responsibility, and the Law (Cambridge: Cambridge University Press, 1999). [Ripstein].

${ }^{9}$ Brudner, supra note 4.

${ }^{10}$ Immanuel Kant, Metaphysical Elements of Justice: part 1 of the Metaphysics of Morals, 2d ed by John Ladd (Indianapolis: Hackett, 1999). [Kant]. A useful collection of Kant's comments on punishment can be found in Jeffrie G Murphy, “Does Kant Have a Theory of Punishment?” 1987) 87 Colum L Rev 509 at 513-16.

${ }^{11}$ Kant, supra note at 10 at para 331.

${ }^{12}$ Ibid at para 331.

${ }^{13}$ Ibid at para 334.

${ }^{14}$ Ibid at para 331.

${ }^{15}$ See especially Kant's discussion of theft, ibid at para 333.

16 The reference here is both to the justification of the institution of punishment and to the justification of the distribution of punishment. Hart's distinction between the questions (supra note 1) was not made by Kant, and it is significant mainly for theories that combine deontological and consequential insights. 
how it does so. For example, is it the message conveyed? Is it a normative resetting of the relationships between the parties or between Wrongdoer and the community? In what way does punishment reset these relationships?

While not articulating the ways in which punishment restores the rightful condition, Kant does imply that equality plays a role in this restoration. Kant addresses equality where referring to the form and amount of punishment: "but what kind and what amount of punishment is it that public justice makes its principle and measure? None other than the principle of equality (in the position of the needle on the scale of justice), to incline no more to one side than to the other. Accordingly, whatever undeserved evil you inflict upon another within the people, that you inflict upon yourself". ${ }^{17}$

In an attempt to articulate reasons justifying the practical application of the worngdoer's hypothetical imperative, Arthur Ripstein has proposed a Rawlsian interpretation of Kant's account. ${ }^{18}$ Ripstein starts with the concept of fair terms of interaction underwritten by the ideas of freedom and equality and manifested as a public standard of reasonableness. ${ }^{19}$ He conceptualizes crime as "the wrongdoer's substitution of his private rationality for public terms of reasonableness." ${ }^{20}$ According to Ripstein, this substitution must be reversed or cancelled. Compensation is insufficient to reverse or cancel such substitution, as it leaves the tradability of rights intact: ${ }^{21}$ Wrongdoer can still choose to violate rights subject to compensation, provided this is rational from her private perspective. Punishment, on the other hand, is sufficient to replace a substitution of the private perspective for the public one. Punishment is justified as it "restores fair terms of cooperation by canceling the claim that private advantage takes precedence. The hard treatment imposed on wrongdoers thus vindicates the reasonable by cancelling the advantage the wrong promised from the point of view from which the wrongdoer acted. In so doing, it also vindicates the rights of the victim in particular". ${ }^{22}$

I would like to draw a distinction between Ripstein's conceptualization of crime and his justification of punishment. Ripstein's conceptualization of crime is highly

${ }^{17}$ Kant, supra note 10 at para 332.

${ }^{18}$ Ripstein, supra note 8; Arthur Ripstein, “Self-Defense and Equal Protection” (1995-1996) 57 U Pitt L Rev 685 (see especially the reference to Rawls at 689). [Ripstein, "Self-Defense”].

${ }^{19}$ Ripstein, supra note 8 at 2; Ripstein, “Self-Defense”, supra note 18 at 689 ("On this Kantian view, reasonableness is tied with the idea of equality. The rood idea is that reasonableness standard provides a like liberty for all compatible with a fundamental interest in the security of those things that are essential to protecting and exercising one's capacity for freedom”).

${ }^{20}$ Ripstein, supra note 8 at 10.

${ }^{21}$ See ibid at 158-59.

${ }^{22}$ Ibid at 161 . 
convincing. Crime is conceived as a denial of Victim's equal freedom (as manifested by a standard of reasonableness). Wrongdoer acts as if Victim's freedom and interest in security are less worthy than her own (thereby rejecting reasonableness in favour of narrow rational calculation). This description accurately captures the wrongfulness of crime.

Ripstein's proposed justification for punishment is less convincing. Ripstein suggests that, unlike compensation, punishment makes crime irrational from the private perspective. By doing so, punishment demonstrates that rights are not tradable, thereby vindicating rights. ${ }^{23}$ The objections to this line of argument are twofold. First, as Brudner has already noted, compensation can also make crime irrational from the private perspective. The fact that Wrongdoer views compensation as a fee does not necessarily turn it into a fee, and thus compensation can actually vindicate rights. ${ }^{24}$ Second and relatedly, if compensation cannot make crime irrational from the private perspective, neither can punishment. Wrongdoer's claim is that the rightful condition can be bought for a certain price. Such an assertion is erroneous and wrongful because it presumes that the rightful condition has no intrinsic value. The wrong cannot be rectified simply by changing the cost of the rightful condition from payment (compensation) to imprisonment (punishment), since, for example, Wrongdoer can still calculate that it is worth her sitting in prison for six years to be followed by a long life of wealth upon her release. In other words, the wrongfulness lies in the reference to the private perspective. Therefore, it cannot be negated by changing the cost calculated from the very same private perspective. ${ }^{25}$

${ }^{23}$ Ibid at 162.

${ }^{24}$ Brudner, supra note 4 at 43.

${ }^{25}$ Possibly, Ripstein analyzes the wrongdoer's challenge as a challenge against the actuality of the rightful condition. The wrongdoer turns reality into one in which there is no rightful condition. Can punishment meet this challenge? Wrongdoing has three aspects. First, it is a right-violation and so it changes the reality of the rightful condition. In addition, it involves two claims, namely (1) that crime pays; and (2) that there is no obligation to maintain a rightful condition. These aspects of wrongdoing are independent from one another. Demonstrating that crime does not pay cannot undo the fact that in reality, rights were violated. It is in the nature of the phenomenological world that it is bounded in time and cannot be changed retroactively. The rightful condition can only be maintained from now on through deterrence, education, etc. which would effectively prevent further violations (i.e. on consequential grounds that go beyond the wrongdoer and his own wrongdoing). And as we saw, demonstrating that crime does not pay also leaves untouched the normative claim that there should be no rightful condition. If this is so, then Ripstein's suggestive account should seek support outside the Kantian presumptions. 
Alan Brudner has recently proposed, in his Punishment and Freedom, a Hegelian justification for punishment. ${ }^{26}$ Brudner's account of punishment focuses on the concept of the dialogic community (or the common will) which he describes as "the mutual recognition of distinct agencies as having final worth”. ${ }^{27}$ Mutual recognition is, primarily, a relationship between a political community and individual agents. ${ }^{28}$ Individual agents are characterized by equal freedom, and Brudner assigns three layers of meaning to such freedom: freedom as formal agency, freedom as real autonomy, and freedom as communal belonging.

"True crimes" are committed within the sphere of formal agency, namely the right to choose or to be undetermined. Such crimes are culpable trespasses of the agent's boundaries that mark her realm of choice. ${ }^{29}$ A true crime is, first an insult to Victim's dignity. It changes the status quo ante of equal freedom, and therefore it denies Victim's equal status. Victim should be compensated for this violation. ${ }^{30}$ Compensation reflects recognition of Victim's private right to choose and brings the parties back to the status quo ante thus restoring equality of status and of freedom. ${ }^{31}$ Second, a true crime poses a challenge to the dialogic community, as it is a denial of rights of agents in general, or a denial of the possibility of such rights. ${ }^{32}$ It is a denial of the principle of mutual recognition as Law. ${ }^{33}$ This denial justifies the imposition of punishment by the dialogic community as a way to "deny the denial" of the authority of mutual recognition as Law. In Brudner's words, “[b]y actualizing a right-denying principle... the wrongdoer gave that principle an appearance of worldly authority, of existential force. He gave it, that is, the appearance of a law... So, by revisiting the self-destructive consequence of the wrongdoer's principle upon him, punishment removes the appearance of its worldly validity and vindicates the worldly authority of Law." 34 Brudner further refers to the other two layers of meaning of freedom: freedom as real autonomy and communal belonging, in order to justify punishment for crimes that do not involve violation of formal agency as well as certain criminal defenses.

Much may be said in favor of Brudner's sophisticated account, with which I agree in the main. Nonetheless, I would like to call certain aspects of it into question. At this point I shall only present a brief summary of the similarities and differences between

${ }^{26}$ Brudner, supra note 4.

${ }^{27} \mathrm{Ibid}$ at 14 . For the form of the dialogical community as a political community see pages 306-07.

${ }^{28}$ Ibid.

${ }^{29}$ Ibid at 37.

${ }^{30}$ Ibid at 39-40.

${ }^{31}$ See Brudner's discussion of compensation and its effects, ibid at 37.

32 Ibid at 39-40.

${ }^{33}$ Ibid at 47.

${ }^{34}$ Ibid. 
his analysis and mine. A more in-depth examination of Brudner's account is conducted in Section VII hereinunder.

As does Brudner, I deem crime to be an intrusion of Victim's boundaries entailing implications for the constitution of agency or personhood. However, I depart from Brudner's account in my analysis of the relationship between Wrongdoer and Victim. I submit that compensation is inadequate to restore the parties' equality of status and freedom, and that punishment is required in order to restore this bilateral equality so as to enable equal constitution of the parties' personhood in the relationship. I reject Brudner's focus on the role the community as a Whole plays in the constitution of agents; instead, I focus on individuals partly constituting one another with the (limited) backup the political authority can provide. Such a line of argument grants only a secondary role to the political community in the conceptualization of crime: when the community imposes punishment it does so on behalf of Victim, and not in its own name. Such a line of argument ${ }^{35}$ is hardly novel; Victor Tadros’ proposed justification for punishment in The Ends of Harm is a recent example of this line of argument. $^{36}$

To construct a well-developed argument regarding equality, I begin with a prevailing ontology of personhood as equally valuable, universal but also situated, and partly bounded. I then analyze crime as an asymmetrical intrusion of Victim's bounded personhood by Wrongdoer. This intrusion creates inequality in the parties' respective boundaries or in their respective personhood. Criminal punishment is then justified as a subsequent intrusion of Wrongdoer's respective boundaries by (the state on behalf of) Victim, an intrusion that works in two ways: it extends Victim's boundaries with respect to Wrongdoer, and it narrows Wrongdoer's boundaries with respect to Victim. As a result, it re-establishes equality of boundaries between the parties, thus restoring their equality of personhood with respect to one another.

The structure of the article is as follows: Section II provides an initial, brief and intuitive statement of the argument. Section III introduces some working assumptions regarding the concept of personhood and the equality of human value. Section IV conceptualizes crime and discusses its various implications from perspective of justice - implications that include a justification for punishment. Section V moves from core crimes to other crimes. Section VI discusses the leveling-down objection. Section VII

${ }^{35}$ In brief, it could be argued against such a move that turns the justification for the state's exclusive authority to impose punishment into a contingent one, relying on the fact that the state is the fittest one for the job. I am not sure that this is so. Like other deontological accounts, my proposed account assumes that the state has a duty to maintain a rightful condition (and thus to vindicate equality between persons). The fact that I do not rely on any threat to the state to justify punishment does not detract from this duty.

${ }^{36}$ Victor Tadros, The Ends of Harm: The Moral Foundations of Criminal Law (Oxford: Oxford University Press, 2011). [Tadros]. 
examines the implications of crime on the relationships between the parties and general society. Section VIII highlights the main differences between the proposed account and existing deontological accounts. And, finally, Section IX concludes with a summary.

\section{(II) The Argument in Brief}

Think of a battered woman. Ignoring the contingencies of her life, she is as autonomous as her partner. But contingencies change this picture. By abusing her, her partner makes her less capable of personal autonomy than he in their relationship. Her personhood with respect to her abusive partner is less robust, her humanity, as manifested in their relationship, is less sound. While still of infinite value, her human properties as they are actualized in this relationship are narrower, less reflective of her, and provide lesser reasons for admiration, unfortunate as this may be. In contrast, her abusive partner's personal autonomy remains untouched. He remains the full person he has always been in their relationship, and his robust-capability for personal autonomy provides reasons for the same admiration as before (even if his moral autonomy does not). In other words, the abusive party imposes on his partner a contingency that creates inequality in their capability for autonomy in the relationship.

The principle of equality requires neutralizing such contingencies as far as possible and creating and maintaining equality of personhood and value. Inequality requires full redress. Equality can be established from the point of redress onwards, for example, if the state interferes to stop the abuse. However, the parties would still remain unequal in their relationship due to the continuing moral significance of the past abuse which remains unchallenged. The past cannot be undone and the woman's capability for autonomy in the relationship cannot be increased retroactively. Neither compensation, nor an apology, nor restoration of equality from the point of redress would make the parties equal in their relationship.

The only way to re-establish equality is to impose punishment on the abusive party. Punishment reduces the abusive party's capability for autonomy in the relationship and at the same time it increases the abused party's capability for autonomy, even if such an increase is fairly minor and indirect. Thus, punishment re-equalizes the parties' personhood in the relationship as a whole and their subsequent positions with respect to one another (though, unfortunately, throughout their lives they will be less capable of autonomy than they would have been absent the incident). Upholding the right to equal personhood, I shall argue, justifies punishment.

But what about entirely random wrongdoing, whose effects on personal autonomy are more remote and less obvious than those in the battered woman example? And what about offences against the public that hardly affect individual autonomy at all? Under one view which has been proposed in the literature, autonomy is just one stance of 
freedom, and freedom is the broader locus of personhood. ${ }^{37}$ Random wrongdoing and offences against the public violate freedom. This view takes freedom to be a broad, rich, and sometimes contradictory concept. Freedom encompasses capacity, capability and actualization; it accounts for a wide range of human expressions, and it underlies most human needs.

In this article, I set aside this robust notion of freedom. ${ }^{38}$ Building upon familiar accounts of the self, I propose a concept of personhood as limited separateness from others that is delineated by boundaries, in concert with a complementary concept of (authenticated) personhood (or minimal true self-identity; or minimal capability to reflect on oneself as one really is). I then characterize the necessary and sufficient prerequisite for punishment as the occurrence of an asymmetrical intrusion of the boundaries that constitute (authenticated) personhood.

\section{(III) Personhood and Equality of Human Value}

The proposed argument presumes three essential characteristics of personhood: (1) limited sociological separateness from one another, which is manifested in contingencies (such as a particular body, particular wills, particular emotions, specific traits, and possibly possession of certain particular objects $\left.{ }^{39}\right) ;{ }^{40}(2)$ minimal

37 This view has its source in Kant's idea of freedom as the only Right. This is Brudner's position (Brudner, supra note 4).

${ }^{38}$ A comment by Meir Dan Cohen, who took a somewhat similar approach to explain responsibility, may fit my aims: "The response is not a solution to, but rather an evasion of, the problems endemic to the free will paradigm. My aim is to provide an alternative unitary account, in light of which we can make sense of much responsibility-talk without encountering the problems presented by the voluntarist perspective.” Meir Dan-Cohen, "Responsibility and the Boundaries of the Self” (1992) 105 Harv L Rev 959 at 960. [Dan-Cohen]

${ }^{39}$ I do not discuss the issue of offences against property here. There may be various arguments in favour and against their criminalisation. However, it is noteworthy that an account of crime as intrusion of personal boundaries does not necessarily exclude criminalisation of attacks over property. Arguably, property is within the realm of personal boundaries. See ibid.

${ }^{40}$ Liberal separateness is sometimes more radical. See, e.g., Robert Nozick, Anarchy, State, and Utopia (New York: Basic Books, 1974) at 30-33; Michael Sandel, Liberalism and the Limits of Justice, 2d ed (New York: Cambridge University Press, 1998) at 51-53. [Sandel]; Charles Taylor, Sources of the Self: The Making of a Modern Identity (Cambridge: Cambridge University Press, 1989) at 5. [Taylor]. Taylor notes that our most basic moral reactions presume the existence of 'others', and that ". [c]ulture and upbringing may help to define the boundaries of the relevant 'others', but they don't seem to create the basic reaction itself". Taylor further notes that "our moral reactions ... have two facets, as it were. On one side, they are almost like instincts... ; on the other, they seem to involve claims, implicit or explicit, about 
true self-identity, which is established as the person reflects on and identifies with his contingent sociological attributes, thereby authenticating his sociological separateness and constituting his independence; ${ }^{41}$ and (3) universal capacity for moral personality, which is realized as the person generates, understands, and follows abstractable and generalizeable, and therefore universal, commands of respect based on reasons. ${ }^{42}$ These commands presuppose contingent sociological separateness and minimal selfidentity, and are directed at maintaining them.

It follows from the above-mentioned presumptions that personal boundaries define and constitute persons. Personal boundaries are the scope inside which the separate and minimally authentic self exists. Personal boundaries have a particularistic aspect and a universal aspect: they are followed-upon universal reasons. Last, personal boundaries are defined in a relational way - for each person with respect to another person(s). ${ }^{43}$

Since they manifest universal reasons to act with respect towards persons, personal boundaries are inherently valuable. ${ }^{44}$ There are two relevant senses of respect, and accordingly two senses in which boundaries are valuable. First, personal boundaries are valuable as constituents of sociological separateness from others. They ensure that persons' bodies, and possessions, and their underlying wills remain separate from one another. As constituents of sociological separateness, boundaries include reasons to avoid intrusion. A woman whose body and will have not suffered intrusion, enjoys

the nature and status of human beings. From this second side, a moral reaction is an assent to, an affirmation of, a given ontology of the human" (ibid). Feminist literature has also been critical of normative assumptions that are allegedly bundled in this ontology. See Robin West, “Jurisprudence and Gender” (1988) 55 U Chicago L Rev 1 at 5 ("According to liberal legalism, the inevitability of the individual's material separation from the 'other', entails, first and foremost, an existential state of highly desirable and much valued freedom: because the individual is separate from the other, he is free from the other").

${ }^{41}$ See Jean Paul Sartre, Being and Nothingness, translated by Hazel E Barnes (New York: Washington Square Press, 1993). [Sartre]. While I draw here on some of Sartre's ideas, I do not wish to accept his moral theory and his notion of freedom. For a similar discussion of self-identity and criminal responsibility see Dan-Cohen, supra note 38 .

42 This premise goes a long way back, but see recently John Rawls, A Theory of Justice (Oxford: Clarendon Press, 1972) at 504-05.

${ }^{43}$ Compare with Brudner's more detailed analysis of boundaries and their relation to rights (supra note 4 at 36-37).

${ }^{44}$ See TM Scanlon, What We Owe to Each Other (Cambridge: Harvard University Press, 1998) at 95-100 and especially at 96. [Scanlon]. My account of boundaries also accords with a stricter Moorian account of value. See GE Moore, Principia Ethica (Cambridge: Cambridge University Press, 1903) at s 13. 
bodily and mental separateness from her partner; she does not merge with his personhood. In this way, she exists as a sociologically distinct person.

Second, boundaries are valuable as constituents of minimal true self-identity, or what I shall call "authenticated separateness" or "self-recognizing separateness". I am referring to the process of reflection on one's distinct attributes - the ones which are objectively one's own - by which a valid sense of self is established. 'Authenticated separateness' is the recognition of oneself as a separate and independent self, which in turn allows the subject to abstract from particularities and identify with the universal, i.e. to act as an agent. As constituents of authenticated separateness, boundaries include reasons to cooperate in the formation of separate self-identities. ${ }^{45}$ Cooperation is pursued by non-intrusion as well as in other ways, for example, in conduct and manners acknowledging expressions of separateness. ${ }^{46}$ A woman who has not suffered intrusion, and whose separateness is acknowledged in conduct and manners, develops a valid self-identity; she recognizes her separation and identifies with her own attributes. In this way, she exists as a self-recognizing person, or as an agent.

I would like to further elaborate this point. Meir Dan-Cohen has already explored the relevance of self-recognition and self-identity with regard to responsibility in criminal law, and we can draw on his insights here.Dan-Cohen discusses the capacity of the self to actively participate in its own constitution. He defines this capacity as "the self's ability to identify with various elements and thereby integrate them into itself, or to distance itself from them by objectifying them and holding them at arm's length." 47 These elements can be mental (for example wills), social (social roles), or physical

45 The two senses of respect, namely non-intrusion and cooperation in constitution of personal identity, bear some resemblance to many distinctions offered in the literature between 'negative liberty' and 'positive liberty' (See Isaiah Berlin, ' Two Concepts of Liberty' in Henry Hardy, ed, Liberty (Oxford: Oxford University Press, 2002) at 169; or between 'formal agency' and 'real autonomy' (Brudner, supra note 4)). For Brudner, for example, real autonomy is different from formal agency in that "the particular agent is not a ghostly self inhabiting a natural body independent of it; rather it is a generic capacity for acting purposively that is individuated in a body moulded to its purpose and executing its self-authored ends.” (Brudner, supra note 4 at 299). Law protects aspects of each of these concepts. In my proposed account, the person is not freedom in various forms. Rather, it is a collection of authenticable attributes constituted by equal socio-moral boundaries. Thus, boundaries are valuable as constituents of humanity authenticated, and they are protected as such.

${ }^{46}$ Reasons to avoid intrusion and reasons to acknowledge in a broader sense are not equivalent. There is a duty not to intrude, and there is no duty to acknowledge in other ways. Non-intrusion constitutes the substrate upon which self-identity develops; and it is also a form of acknowledgement. Other forms of acknowledgment are less fundamental. However, for our purposes it is important that both types of reasons exist and accordingly, boundaries are valuable in these two senses.

${ }^{47}$ Dan-Cohen, supra note 38 at 966. 
(body, property). ${ }^{48}$ I would like to focus only on the elements without which no intelligible notion of personhood is possible, such as the body or the will. By identifying with these basic elements, the person forms a self-identity (rather than an identity that is merged with others). This allows the person to then abstract from this very self-identity and act upon universal reasons as an agent. ${ }^{49}$

Yet the self is not the only participant in its own constitution in processes of identification. ${ }^{50}$ Identification is, actually, determination of the person's boundaries. As we saw, boundaries are followed-upon reasons, or particularized concepts; and particularization involves not only the self but also others. This can be demonstrated as follows: Reason entails that the body is to be acknowledged as one's own separate body and respected as such; society fills this demand with real content and determines in what particular ways this occurs (subject to constraints that the notion of respect dictates). Identification is thus a cooperative process in which persons form separate self-identities. It is connectedness affirming its opposite: separateness. Boundaries are valuable as constituents of these separate self-identities, or of self-recognizing and authenticated personhood.

The number of boundaries constituting (authenticated) personhood in any given relationship is infinite, as there are infinite concretizations for every reason to command respect (the number of non-intrusions, whether or not accompanied by other respectful conduct). Accordingly, the value of each person is infinite. ${ }^{51}$

${ }^{48}$ Ibid at 967-68, referring to Harry G Frankfurt, The Importance of What We Care About (Cambridge: Cambridge University Press, 1988); Sartre, supra note 41; M Merleau-Ponty, Phenomenology of Perception, translated by Colin Smith (London: Routledge, 2002); Erving Goffman, Encounters: Two Studies in the Sociology of Interaction (Indianapolis: Bobbs-Merrill, 1961).

${ }^{49}$ For some interesting comments on identification and reflection see J David Velleman, 'Identification and Identity' in Sarah Buss \& Lee Overton, eds, Contours of Agency: Essays on Themes from Harry Frankfurt (Cambridge: MIT Press, 2002) at 91.

${ }^{50}$ Dan-Cohen, supra note 38 at 968.

${ }^{51}$ All of this is not to say that our boundaries are the only valuable feature we hold, or even the only infinitely valuable feature that we hold. We can, for example, think that our intellect is constitutive of our personhood and valuable as such; and further that each person consists of an infinite number of intellectual instances or incidents. This would lead us to conclude that each person is of infinite value. However, this premise would not lead to any conclusions regarding equal claims against one another, at least not directly. Boundaries are unique as they involve claims against others.

Furthermore, value of contingent properties (properties that are not essential for personhood) cannot underlie an argument from equality of the type I would like to advance here. 
However, infinite value does not yet mean equal value. ${ }^{52}$ Infinities are not necessarily equal. Georg Cantor's set theory suggests that infinite sets can be of different magnitudes provided one set contains elements for which there is no correlation in the other set. ${ }^{53}$ We can assume, accordingly, that A has a (valuable) boundary which B lacks. B may still have an infinite set of boundaries and accordingly infinite value, but B's set of boundaries and corresponding magnitude of value would be smaller than A's.

In the absence of contingencies, human beings are equal in the infinite value of their (authenticated) personhood. They all have the same constitutive boundaries with respect to one another, and accordingly the same magnitude of infinitely valuable attributes. However, contingencies can alter this basic condition of equality. Some people's constituents are less robust than others'. For instance, some people's boundaries are contingently intruded within one or several of their relationships with others. This affects the magnitude of the value of (authenticated) personhood in these relationships. The magnitude of infinite value of (authenticated) personhood is thus contingent.

The normative principle of equality is a "contingencies neutralizing” principle. It provides reasons to promote as far as possible the a priori equal magnitude of value of (authenticated) personhood of all persons. In other words, it provides a reason to equate persons' boundaries. This reason is not necessarily a conclusive one, but it is weightier where the inequalities are unjust, namely where they can be attributed to the persons whose boundaries are more extensive.

Boundaries also allow persons to pursue their conceptions of the good. Without boundaries, persons are not independent and cannot identify their own particular good or pursue it. In the proposed analysis, boundaries do not have any distinct and additional value as facilitators of pursuit of the good. The good is not valuable in the sense that I am discussing here, namely inherently. ${ }^{54}$ Accordingly, equality of human value does not entail equality of claims for the good, in addition to claims for equal (authenticated) personhood. ${ }^{55}$ There may well be an additional principle of minimal

${ }^{52}$ Infinity is a difficult concept that has been discussed in philosophy and mathematics for centuries. The literature is vast, but one insightful example is Graham Oppy, Philosophical Perspectives on Infinity (New York: Cambridge University Press, 2006).

${ }^{53}$ For an accessible explanation of Cantor's set theory see Joseph Warren Dauben, Georg Cantor: His Metaphysics and Philosophy of the Infinite (Princeton: Princeton University Press, 1990).

${ }^{54}$ And the mere pursuit of some ends is not valuable. See Joseph Raz, The Morality of Freedom (Oxford: Clarendon Press, 1986) at 380-81. [Raz].

${ }^{55}$ Nevertheless, claims from equality of human value often coincide with claims for the good. This is so because of the close connection between the concept of personhood and the concept of the good (for example, in classical liberal theory 
and equal claims for the good, but this principle does not flow directly from equality of human value. For purposes of this paper, I shall assume such a principle without exploring its source.

In summary: (1) personhood is infinitely valuable; (2) personhood consists of boundaries that one has with respect to another which are authenticated in cooperative processes of mutual recognition and respect; (3) absent contingencies, personhood is exactly the same infinitely valuable substance for all - for each boundary that a person has, there is a correlating respective boundary held by all other persons; (4) contingencies change the picture in a way that does not affect the infinity of human value of (authenticated) personhood, but does affect the magnitude of this infinite value; (5) the principle of equality is contingencies-neutralizing according to which there is a reason to re-equate persons' magnitude of value by re-equating their boundaries of (authenticated) personhood. This reason is strongest where contingencies are attributable to the persons whose boundaries are more extensive; (6) we can further assume a reason to re-equate the capacity to pursue the good, possibly in light of the connection between personhood and the good.

\section{(IV) Intrusion of Respective Boundaries and its Moral Consequences}

The discussion in section III has shown that individuals have minimal and equal respective boundaries from (authenticated) personhood, and possibly also minimal and equal claims for the good. This section examines how crime affects persons' boundaries and their good, and the moral consequences of such effects.

I begin by ruling out the possibility that crime should be analyzed primarily as affecting Victim's minimal good and her minimal boundaries with respect to the offender. Next, I demonstrate that crime violates equality between the parties - both equality of the capability to pursue the good and equality of constituent boundaries. Remedies for the violations of equality are then examined. It is demonstrated that compensation can answer claims of equality of the capability to pursue the good, however, claims of equality of constituent boundaries can only be remedied through the imposition of punishment. I conclude that crime should be conceptualized as an asymmetrical intrusion of Victim's boundaries from (authenticated) personhood, and

personal autonomy is often regarded both as an ultimate good and as a constituent of personhood). See, e.g., Taylor, supra note 40 at 14-15 ('To understand our moral world we have to see not only what ideas and pictures underlie our sense of respect for others but also those which underpin our notions of a full life... . [T] hese are not two quite separate orders of ideas. There is a substantial overlap or, rather, a complex relation in which some of the same basic notions reappear in a new way'). 
that this conceptualization provides a justification for punishment. Finally, this section briefly discusses the amount of punishment.

\section{(IV)(1) Intrusion of Victim's Minimal Boundaries}

Crime detracts from Victim's minimal capability to pursue the good and intrudes on Victim's minimal boundaries of (authenticated) personhood. However, this aspect of criminal conduct does not, itself, justify punishment. The reason for this is simple: criminal punishment is not necessary to remedy a claim of deprivation of minimal capability to pursue the good, and it is not helpful in remedying a claim of intrusion of minimal boundaries of (authenticated) personhood.

Crime undermines the conditions allowing the will to extend effectively over a range of ends (one's conception of the good), and thus it may prevent Victim from pursuing even a minimally good life. Claims for minimally good life can justify compensatory obligations. Ensuring minimal prospects for a good life requires a sufficient range of achievable meaningful possibilities (potential ends). ${ }^{56}$ In the vast majority of cases, money can buy such (replaceable) meaningful possibilities. ${ }^{57}$ Therefore, compensation can take Victim back above the necessary minimum. Sometimes money cannot buy the identical possibilities that were lost, but it can buy other fulfilling possibilities, thereby ensuring that the overall capability to pursue a good life remains above the minimum. If compensation can remedy the violation, there is no need for punishment.

Claims from minimal (authenticated) personhood, on the other hand, cannot justify compensatory obligations, or an obligation to be punished, or any other obligation. This paper delves further into this subject later, ${ }^{58}$ but for now it is enough to note that boundaries from (authenticated) personhood are valuable in themselves. They do not draw value from something else that money can buy or that punishment can somehow create. Compensating Victim or punishing Wrongdoer does not undo the intrusion of Victim's minimal boundaries in any way. When one's existence as an independent person is undermined, only retroactive reestablishment of his independent existence could remedy, but such retroactive reestablishment is impossible. Accordingly,

${ }^{56}$ Autonomy has been interpreted differently by different authors, but the above characteristic seems to be consensual. For different interpretations of autonomy see Raz, supra note 54; Joel Feinberg's concept in Joel Feinberg, Harm to Self: The Moral Limits of the Criminal Law, vol 3 (Oxford: Oxford University Press, 1986) at 28-51, see especially at 47; Gerald Dworkin, “The Concept of Autonomy” in John Christman, ed, The Inner Citadel: Essays on Individual Autonomy (New York:

Oxford University Press, 1989) at 54; Donald Dripps, "For a Negative, Normative Model of Consent, with a Comment on Preference-Skepticism” (1996) 2 Legal Theory 113; Grace Clement, Care, Autonomy and Justice: Feminism and the Ethics of Care (Boulder: Westview Press, 1996).

${ }^{57}$ See further discussion in subsection (IV)(3).

${ }^{58}$ See further discussion in subsection IV(4). 
neither compensatory obligations nor criminal punishment can be justified on the basis of claims with respect to minimal (authenticated) personhood.

\section{(IV)(2) Inequalities and Their Moral Implications}

As we saw, while crime detracts from Victim's minimal boundaries and minimal capability to pursue the good, this alone does not justify punishment. Thus an examination of crime as a violation of equality - both of the capability to pursue the good and of boundaries - is appropriate.

Crime changes the a priori condition of equality in the relative positions of parties with respect to one another in the two above-mentioned respects. First, Wrongdoer detracts from Victim's prospects for living a good life: Wrongdoer reduces Victim's achievable ends and therefore also Victim's prospects of living in compliance with his conception of the good. Wrongdoer's crime effectively pushes certain ends outside the reach of Victim's will. In contrast, Wrongdoer does not suffer any such contingent consequences. Her prospects for a good life remain the same. ${ }^{59}$ Thus, Victim has a claim of equality in the capability to live according to his conception of the good. Victim's conception of the good is not inherently valuable, and hence it is replaceable, with the result that any reduction in his prospect of achieving it is compensable. It is hard to undo grave deprivations from the good, as in most cases victims would not have sold the basic conditions that allow a good life for any amount of money. ${ }^{60}$ Nevertheless, it may be assumed that full or at least almost full compensation for a reduction in achievable ends is possible. All the money in the world can help in achieving certain goals that Victim would not have even considered trying to achieve absent such compensation. ${ }^{61}$ Compensation would thus return the parties to equal positions. Accordingly, an inequality in the prospect for a good life can justify compensation.

${ }^{59}$ It is indeed possible that Wrongdoer's prospect of a good life is also reduced by the intrusion, for example because Wrongdoer is injured while committing the wrong. Yet this reduction is irrelevant for evaluation of equality between the parties. As explained above, the principle of equality is a contingencies-neutralizing principle. It requires neutralizing contingencies affecting equality between persons. In the case of injured Wrongdoer, the injury is not a contingency. It is attributable to Wrongdoer as a product of a blameworthy act of will. Accordingly, it should be ignored. See further discussion in section VI.

${ }^{60}$ The holder of an entitlement protected by a property rule determines the price of the entitlement. See Guido Calabresi \& A Douglas Melamed, "Property Rules, Liability Rules, and Inalienability: One View of the Cathedral” (1972) 85 Harv L Rev1089 at 1092.

${ }^{61}$ It is not clear that this is true; it is clearly untrue in cases of homicide. However, it may be assumed that it is largely true for purposes of this discussion. 
Second, by intruding on Victim's boundaries, Wrongdoer narrows Victim's boundaries from (authenticated) personhood with respect to Wrongdoer without a comparable narrowing of Wrongdoer's boundaries with respect to Victim. ${ }^{62}$ The result is that Victim is overall less immune to imposed intrusions by Wrongdoer than Wrongdoer is immune to intrusions by Victim; or in other words, the parties' respective boundaries are no longer equal and symmetrical. The intrusion creates an unfair inequality in the parties' constituent boundaries from (authenticated) personhood with respect to one another. ${ }^{63}$

Much like the initial state of equality, this last inequality is morally relevant in two ways - as inequality of separateness and as inequality of authenticated separateness (or minimal self-identity). Let us examine these two dimensions of the inequality in boundaries.

First, the inequality is morally relevant as an inequality in boundaries from separate personhood. Wrongdoer imposes a contingency on Victim's boundaries. As we saw, boundaries have sociological dimensions and moral dimensions. By intruding the boundaries, Wrongdoer denies their moral dimension, and thus Victim's separateness from Wrongdoer remains limited to the sociological realm. As such it is conditional and minimal, in a way similar to the separation between persons and objects. On the other hand, Wrongdoer's separate personhood remains a robust one having both sociological and moral dimensions: Wrongdoer is not intruded upon contingently, and the distinction between himself and Victim is not blurred other than by a noncontingent act of his own will.

This inequality is far-reaching, but not radical. The inequality is far-reaching inasmuch the parties' respective realms of non-interference are no longer equal; in their particular relationship, Wrongdoer maintains one boundary for which Victim has no correlative boundary, and thus Victim suffers a lower magnitude of value than Wrongdoer. Nonetheless, the inequality is not radical, or rather does not go to the infinity of the parties' human value: both Wrongdoer and Victim still have an infinite number of boundaries with respect to one another, and accordingly Victim still maintains his infinite human value, much like Wrongdoer. Nevertheless, this inequality may be morally meaningful as a symbolic signifier of (unequal) moral status; and it may also adversely affect Wrongdoer's reasons to develop internal

${ }^{62}$ This does not mean that the attack is legitimate provided that Wrongdoer is willing to a symmetrical downgrade. First, because she still forces the 'symmetrical' downgrade, therefore the downgrade cannot be regarded fully symmetrical. Second, because it still detracts from Victim's (and-Attacker's Wrongdoer's) minimal boundaries.

${ }^{63}$ Analytically, this last inequality can be described as having two complementary aspects: first, respective inequality of bodily (or other) scope; second, respective inequality of the scope of the will: it was-Attacker Wrongdoer who chose to change the respective boundaries and this fundamental choice was imposed on victim. 
attitudes of admiration towards Victim's diminished personhood. While morally significant, it is not clear that this inequality, alone, can give rise to a requirement for punitive action.

Second, the inequality is morally relevant as an inequality of boundaries of (authenticated) personhood or authenticated separateness. Since separation from Wrongdoer has almost entirely disintegrated, Victim becomes unable to authenticate his (non-existent) separateness and form a self-identity in his relationship with Wrongdoer. Thus, for example, Victim may become less capable of identifying with his own body. Wrongdoer's corresponding ability to form a self-identity in the relationship remains unaffected; and it may be further noted that his self-identity may even falsely extend to Victim as one of his objects of possession. Hereinunder follows an examination of this inequality in more detail.

Constitution of self-identity is a social process requiring Victim's participation. Since Victim has lost a boundary in his relationship with Wrongdoer, he has become less capable of identifying with the intruded attribute. This reduction in the capability to identify becomes a permanent feature of the relationship evaluated as a whole. T.M. Scanlon's description of wrongdoing captures this point: "If I have injured someone by failing to take their interests into account in the way one should, then my relation with them is already altered by that fact, whatever they do. They may retaliate in some way, or they may forgive me... It does not alter the wrong that has been done." ${ }^{64}$ If the wrong is always present in the relation between Wrongdoer and Victim, then Wrongdoer's grip of Victim is constant.

Wrongdoer's constant grip of Victim affects Wrongdoer's reasons for action in the relationship. Even if Victim's infinite boundaries provide a priori reasons to cooperate with Victim in the process of self-constitution, these reasons are diminished by Victim's reduced ability to participate in the process. There is no reason to allow a place for someone who cannot fill it up. Things are not different even if Victim is unaware of the violation. Victim may think that his identity in the relationship is just as authentic as Wrongdoer's, but as a matter of fact, Victim's identity is false Victim's identity is not a self-identity, because Victim does not have a fully separate self in the relationship with which he can identify. Wrongdoer's grip is present, turning the process of identification into a hollow one. Accordingly, this last inequality - the inequality in (authenticated) personhood - is a radical inequality, affecting Wrongdoer's reasons to respect Victim by cooperating in constitution of his self-identity. ${ }^{65}$

${ }^{64}$ Scanlon, supra note 44 at 272.

65 To be sure, it is indeed possible that the moment Victim's boundaries are at least partly extended once again, for example, following the imposition of punishment, Wrongdoer will have a special obligation to respect it in the broader sense (allowing authentication). But until then, the decrease in the magnitude of Victim's infinite 
In further examination: Perhaps the inequality of boundaries is even more fundamental: perhaps it does not go only to a specific socio-moral boundary, but to the entire existence of socio-moral boundaries. The initial boundaries are not justified by any particular will; they are given by reason. These boundaries constitute the particular will as a socio-moral phenomenon and take precedence over this will and exist beyond its reach. Where the authenticated particular will extends to the boundaries that constitute it, the authenticated will "reverses the order" and denies personhood altogether. Wrongdoer attacks one of the preconditions of Victim's personhood, while Victim still accepts Wrongdoer's personhood. ${ }^{66}$

Undermining one boundary does not amount to a denial of boundaries altogether. By way of analogy, we can, at a single instance, disobey one command given by an authority without negating its authority across the board. Moreover, even if Wrongdoer acts in such a way as to logically deny Victim's personhood, this denial is mostly symbolic. As such it can hardly have any implications for Victim's status. There is no reason why Wrongdoer's "naked” statement should carry more weight than Victim's opposite statement, thereby having implications for Victim's status in the relationship. However, such fundamental inequality can perhaps arise in extreme genocidal situations, where humanity is totally denied. This is not the place to develop this hypothesis.

In summary: apart from the claims of inequality of the capability to pursue the good for which compensation is due, the inequalities that require redress following the commission of a crime are (1) an inequality of boundaries of personhood signifying the parties' unequal moral standing and affecting Wrongdoer's reasons to form an internal attitude of admiration towards Victim. Yet symbols and internal attitudes are usually outside the realm of justice and the reach of criminal law; and (2) the derivative inequality of boundaries of (authenticated) personhood in the relationship, as inequality in reasons to respect one another by cooperating in processes of selfconstitution and authentication. This last inequality of value is immoral and unjust; it is morally and legally significant.

\section{(IV)(3) Why Are Non-Punitive Responses Incapable of Re-Equalizing Boundaries?}

We saw that crime creates inequality in the capability to pursue the good, which compensation can remedy. We then saw that crime further creates inequality in boundaries, and that some aspects of this inequality are morally and legally relevant.

value means that Wrongdoer has fewer reasons to respect Victim in the abovementioned broader sense than Victim's respective reasons.

${ }^{66}$ This argument is similar to Brudner's more far-reaching claim that a violation of right signifies not only a denial of the agent's rights, but an overall denial of the possibility of rights. See Brudner, supra note 4 at 40. 
This subsection starts examining possible remedies for the inequality in boundaries. It explains why neither compensation nor a public apology can redress this inequality and re-equalize the parties' boundaries. The following subsection will demonstrate how punishment may provide the remedy to re-equalize these boundaries.

The parties' respective boundaries have to be re-equated so that the magnitude of their infinite human value reverts to the same once again. Here, compensation is inappropriate as boundaries are valuable in (and for) themselves. They constitute the person as an independent thinking person, and as such they are the source of any other value that replaceable things may have for that person. This point can also be put as follows: imposition of mere compensation to remedy inequality of boundaries amounts to altering the rule which applies to Wrongdoer from a property rule to a liability rule without enabling the same for Victim. ${ }^{67}$ It is easy to see that this would be unfair. The choice between property rules and liability rules reflects a decision regarding respective boundaries. ${ }^{68}$ Liability rules require suffering intrusions of boundaries subject to compensation, and accordingly, they do not protect boundaries. Property rules prevent intrusions, thereby protecting boundaries. ${ }^{69}$ Applying a liability rule for Wrongdoer's conduct with respect to Victim while maintaining a property rule for Victim's conduct with respect to Wrongdoer is downgrading Victim's position with respect to his relationship with Wrongdoer. It narrows Victim's boundaries without doing the same to Wrongdoer. ${ }^{70}$ For this reason, it does not provide a remedy for the inequality created by the intrusion. Opting for a liability rule for both Wrongdoer and Victim is also inappropriate. It would be equivalent to opting for no rights for all, and claiming that, in doing so, everyone's humanity is respected. Boundaries ought to be minimal and equal, and not only equal. In other words, when determining the rules of the game, certain property rules must be maintained.

A public apology accompanied by a promise not to repeat the conduct does also not re-equalize respective boundaries. As we saw, wrongdoing alters the relation between the parties, and this alteration cannot be retroactively undone. A public apology accompanied by a promise not to repeat the conduct does not replace the boundary that was lost when the crime was committed; it neither changes the past, nor does it build new equivalent boundaries. Accordingly the inequality in the relationship of boundaries from personhood remains.

${ }^{67}$ Calabresi and Melamed, supra note 60 at 1125.

68 This is implied also in Avihay Dorfman's Hegelian insight that property rules reflect the duty to treat others with respectful recognition. See Avihay Dorfman, "The Society of Property” (2012) 62 UTLJ 563.

${ }^{69}$ For a similar, but not identical account, see Wojciech Sadurski, Giving Desert its Due: Social Justice and Legal Theory (Holland: Reidel, 1985) at 104-05.

${ }^{70}$ Clearly, unequal application of the rules would change the rules, with all the relevant ramifications that this may have. 
Yet an apology and a promise do have certain implications for the inequality in boundaries of (authenticated) personhood: while not completely redressed, because Wrongdoer's grip of Victim will always remain an aspect of their relationship, the inequality is indeed diminished. The apology and promise transform it into something that belongs in a different stage of the relationship, thus enabling Victim to distance himself from it to a certain extent. Victim is therefore more capable of forming a selfidentity in the relationship, and Wrongdoer has somewhat stronger reasons to participate in the constitution of Victim's self-identity. This explains why an apology and a promise have value, and why they may play a role in reducing the sentence.

After determining that compensation does not redress the inequality of boundaries from (authenticated) personhood, and that an apology and a promise can do so only partially and to a limited extent, the next subsection seeks to examine whether and how punishment can redress the inequality.

\section{(IV)(4) The Moral Consequences: Punishment}

While the intrusion of Victim's boundaries cannot be undone through compensation or an apology (or in any other way), the inequality that it creates between Wrongdoer and Victim can be redressed through an injunction (where appropriate) accompanied by punishment. An injunction is required to stop the intrusion. Punishment is required to re-establish equality.

Punishment remedies inequality in two ways: first, punishment is an intrusion that downgrades Wrongdoer's position, narrowing down Wrongdoer's boundaries with respect to (the state on behalf of) Victim. This intrusion diminishes Wrongdoer's separateness from (the state on behalf of) Victim, thereby also decreasing Wrongdoer's capability to authenticate her separateness from (the state on behalf of) Victim. The state acts here as an independent agent. As such, it has a relation to Wrongdoer similar to the relation between persons, and it is capable of disrupting self-identification processes. Thus following the imposition of punishment, Wrongdoer becomes less capable of forming a self-identity. As a result, Wrongdoer might, for example, become less expressive of her body or her will whenever she communicates with prison staff or with other officials representing the state (and potentially also with other members of the community). ${ }^{71}$ This narrowing of boundaries is done on behalf of Victim, and thus it should be taken as a narrowing of boundaries in the relationship between Wrongdoer and Victim rather than in the

${ }^{71}$ To be sure, she might not become less expressive; but then her expressions of separateness would not be authentic, since they would not rely on any objective reality of separateness. In the absence of real separateness, there are fewer reasons to cooperate with Wrongdoer's (futile) authentication processes. 
relationship with the state or with any specific state official. In the moral sphere, the players are Victim and Wrongdoer; the state and its officials are only mediators. Accordingly, punishment reduces the magnitude of Wrongdoer's value of (authenticated) personhood in her relationship with Victim.

Punishment also remedies inequality in another way: it upgrades Victim’s position, re-increasing to some, admittedly limited, extent his boundaries with respect to Wrongdoer. Punishment consists of an intrusion of Wrongdoer's boundaries and a simultaneous nullification of Wrongdoer's permission to defend himself from this intrusion. Nullification of Wrongdoer's permission to defend himself from intrusive (state officials on behalf of) Victim increases the realm of non-intrusion of (state officials on behalf of) Victim. While doing so, it also increases Victim's objective ability to authenticate his separateness. Having more extensive boundaries, Victim now has better conditions allowing for the formation of a self-identity (regardless of his subjective background and emotions which may or may not allow actually making use of these conditions). ${ }^{72}$ Thus, Wrongdoer has more reasons to cooperate with Victim in authentication processes, and the magnitude of Victim's value in the relationship is increased.

Moreover, as long as imprisoned, Wrongdoer is practically prevented from crossing Victim's boundaries in any legitimate or illegitimate way. Preventing all (or almost all) intrusions gives Victim extra-scope with respect to Wrongdoer, instead of some of the scope lost as a result of the original intrusion. The intrusions that are now prevented are mostly minor ones (hence legal, even if immoral). They are hardly as invasive as the original intrusion. Nevertheless, the combination the two implications - downgrading Wrongdoer's position and upgrading Victim's position in more than one way - can bring the parties back to symmetrical positions in terms of their respective boundaries.

It could be argued that punishment does not redress the inequality, at least not entirely: it does not answer for the fact that Wrongdoer imposed his will and changed the respective boundaries. The decision to change the balance was ultimately Wrongdoer's. This argument presumes that Wrongdoer chose or willed not only to intrude, but also to be subjected to the consequent punishment. ${ }^{73}$ But this presumption adopts a rigid and deliberately theoretical interpretation of choice or will. It suits public reason accounts that justify punishment by reference to public standards and their significance for society as a whole, rather than by reference to individuals in particular relationships. If choice is taken as an actual and significant act of authentic

${ }^{72}$ For a more extensive discussion of Victim's boundaries, see Lex Talionis in subsection (IV)(6).

${ }^{73}$ Such presumptions underlie Hegelian claims that punishment is an act of respect towards the wrongdoer. 
will, then Wrongdoer does not choose to be punished; punishment is imposed on him by (the state representing) Victim, and so respective boundaries are re-equalized.

\section{(IV)(5) The Amount of Punishment}

Are all intrusions equivalent, or do they violate equality to different extents? It could be claimed that an intrusion has neither extent nor depth. The spatial analogy is nothing but an analogy, and there is no real space or realm that can be intruded to any specific extent. ${ }^{74}$ It could also be claimed that even if intrusions do differ in extent or depth, the differences are not expressed or measured in terms of autonomy or wellbeing, and accordingly it is not essential that punishment detract from autonomy and well-being (so long as it forms an intrusion). ${ }^{75}$

Let us first address the alleged equivalency of all intrusions. The spatial analogy is indeed just an analogy; but it is an illuminating one. Our boundaries are not of equal fundamentality for our separateness. Neither are they of equal fundamentality for our self-identity which is "made up of a relatively hard core that radiates out with decreasing density." ${ }^{76}$ While slightly pushing Victim may indeed detract something from Victim's realm of non-interference and accordingly narrow the scope of Victim's socio-moral personhood as it stands with respect to Wrongdoer, raping Victim comes close to denying her separate bodily and mental existence altogether. In such a case, Wrongdoer's action is one in which the special moral separateness of persons from one another is almost completely cancelled, even though there remains the limited sociological separateness of persons from things. ${ }^{77}$ Furthermore, Victim's ability to authenticate her separateness in the relationship and to form a self-identity is lost as she becomes as much a part of Wrongdoer's overly extensive self as any of Wrongdoer's objects of possession. The denial of moral separateness is so extensive

${ }^{74}$ Brudner, who describes the criminal conduct as intrusion of the realm of formal agency, moves away from the concept of formal agency to a concept of real autonomy in order to explain the amount of punishment. See, e.g., Brudner, supra note 4 at10, 55-56.

${ }^{75}$ For the relation between rights and well-being see Tadros, supra note 36 at 86 .

${ }^{76}$ Dan-Cohen, supra note 38 at 967.

77 When Wrongdoer rapes Victim he obviously presupposes that Victim is sociologically separate from him; but sociological separateness is not full separateness which has a further moral dimension. Knowing that Victim has a will but treating this will as insignificant is, perhaps, like climbing over a neighbour's fence: it does not make the fence disappear, but it makes the separation between the actor and the neighbour less sound. Furthermore, the sociological separateness is itself undermined by the act of rape. Finding ways to disregard Victim's will is, perhaps, like leaning ladders on a neighbour's fence. While still there, the fence is less of a fence when it has ladders leaning all over it. 
in the case of rape because, for various reasons, ${ }^{78}$ the "don't touch without permission" imperative is stronger with respect to intimate body parts; furthermore, there is an additional "don't penetrate without permission” imperative, with penetration being the most extreme intrusion of the body; and finally, and perhaps most importantly, rape breaks apart the unity of Victim's personhood. Wrongdoer rips, as it were, her body apart from her by possessing it as one of his own objects of possession, ${ }^{79}$ thereby collapsing almost every distance between himself and Victim and eliminating her capability to authenticate (whatever is left of) her separateness altogether. ${ }^{80}$ Based on the above, the extent of inequality resulting from a slight push is much milder than the inequality resulting from rape. Indeed, it is so mild that state punishment is, all things considered, probably unjustified.

We can now address the amount of punishment and its relation to Wrongdoer's wellbeing. ${ }^{81}$ Measuring the relative extent of an intrusion of boundaries involves defining an elaborated ontology of the person (including such things as life, a human body, a rational will manifested in agency, subjectivity manifested, amongst other things, in possession, etc.), evaluating the significance of each personal attribute for our separateness, and its correlating significance in a scalar image of the self, considering the ways in which each is intruded upon (more or less extensively; with or without affecting the unity of the person; etc.), and then evaluating the moral significance of the intrusion at issue. This task is complex, and I shall not pursue it here. My aim in this article is merely to point to the principles which would allow measuring inequality with regard to respective boundaries.

Normally there would be a correlation between the extent of the intrusion and its effects on Victim's capability to pursue one's good. This has to do with the connection between the concept of personhood and the concept of the good; each affects the

78 These may have something to do with the importance of sexuality as a component of the Self: the same way we cannot conceive of a person without a body, we find it difficult to think of an entirely sexless (and hence also gender-free) person.

${ }^{79}$ Compare with Sandel's illuminating description of the self as a subject of possession, supra note 40 at 54-57.

${ }^{80}$ Kant describes the subject's possession of things in terms of other people's obligation to refrain from using the things possessed by the subject. It is interesting that when describing this relation of possession, he also resorts to spatial metaphors, referring to the joining of the Will of the subject with the object (though he clarifies that these are concepts of reason rather than any actual physical relations). See Kant, supra note 10 at para 254.

${ }^{81}$ Measuring inequality is usually not simple, as equality is a complex and multifaceted notion. See Larry S Temkin, Inequality (New York: Oxford University Press, 1993), especially his proposed measurement on pages 147-50. [Temkin]. I do not discuss here general equality, but equality in one relatively simple respect. Yet this too requires a detailed procedure. 
other. Considering this association between these two concepts, a useful way of evaluating inequality in respective boundaries is evaluating inequality in the capability to pursue the good following the intrusion. Such evaluations are less complex and potentially helpful. They are conducted routinely in tort cases, though there they are translated to monetary terms. In the criminal context, they should be translated to terms of imprisonment that would form an intrusion of boundaries that would redress the inequality caused by the crime.

Since there is such a correlation between boundaries and the capability to pursue one's good, re-equalization of Wrongdoer and Victim's boundaries almost inevitably involves deprivation of Wrongdoer's capability to pursue his good. Wrongdoer cannot lose something from his personhood without at the same time losing something from his ability to live a good life. For this reason, punishment involves deprivation of well-being.

\section{(IV)(6) Lex Talionis?}

Kant's reference to the principle of equality to justify punishment has been subject to strong criticism. Andrew von Hirsch has expressed reservations regarding Kant's alleged rejection of the principle of proportionality - a rejection that would result in harsh punishment: "Kant simply asserts that talionic equality should be the criterion for deserved punishment, ruling out less draconian criteria such as the principle of proportionality". ${ }^{82}$ While it is arguable that Kant's position can actually accommodate a principle of proportionality, it must be admitted that Kant's endorsement of the death penalty does indicate potential harshness.

It may be argued that the same holds true for the theory proposed here: If the aim is to restore equality in the relationship between Wrongdoer and Victim, "an eye for an eye” is probably the most appropriate punishment. Yet this proposal entails several reasons why "an eye for an eye" is neither an accurate punishment nor a justifiable one, and why draconian punishment is not a necessary or even possible feature of a theory of punishment based on equality.

First, criminal punishment is comprised of a physical element in combination with a non-physical element of public condemnation. Public condemnation includes intrusion into Wrongdoer's realm of privacy (the sphere of Wrongdoer's identity that is Wrongdoer's own, not to be shared by others). This intrusion interrupts authentication of separateness from all others including Victim, thereby detracting from the magnitude of Wrongdoer's value in his relationship with Victim. If we take this non-physical punishment into account, the need for further physical intrusion is reduced.

${ }^{82}$ Andrew von Hirsch, "Proportionality in the Philosophy of Punishment” (1992) 16 Crime and Justice 55 at 61. 
Second, Wrongdoer's intrusion of Victim detracts from the value of Wrongdoer's moral autonomy in general and thus also in her relationship with Victim. This is the natural punishment that Wrongdoer suffers. Moral autonomy is a fundamental constituent of personhood and it is valuable as such. Despite Kant's reservations, ${ }^{83}$ in the inequality of boundaries account, this natural punishment should also be considered when calculating the amount of punishment needed in order to re-equate the parties' positions.

Third, criminal punishment upgrades Victim's relative position in his relationship with Wrongdoer to some extent. Usually, the realm of Victim's boundaries ends where Victim intrudes upon Wrongdoer, since such conduct allows Wrongdoer to intrude upon Victim in self-defence. But where punishment is imposed, (the state on behalf of) Victim is allowed to intrude upon Wrongdoer without becoming susceptible to a defensive response, thus gaining an extra boundary on behalf of Victim. ${ }^{84}$ This is in the very essence of punishment: it entails the nullification of the vulnerability to selfdefence. Admittedly, this extension of boundaries is limited. The additional boundary is of a different quality than the one which was intruded upon. Rather than being an unconditional boundary, it is conditioned on the unusual punitive act. Thus, this extension of boundaries cannot reestablish Victim's pre-transactional boundaries; it can only advance to some extent the re-establishment of equality.

There are additional ways in which punishment upgrades Victim's position in the relationship. At least where imprisonment is imposed, Wrongdoer is effectively prevented from interfering with Victim in any way. Victim therefore gains an extensive and unusual range of immunities from Wrongdoer, though the additional immunities are from merely mild intrusions.

Moreover, we can assume that for every two persons there is a certain likelihood of mutual wrongdoing (the pre-transactional likelihood). We can further assume that in the relationship between Wrongdoer and Victim, punishment reduces the likelihood of further wrongdoing by Wrongdoer, as it deters Wrongdoer from such further wrongdoing. If private deterrence is sufficiently effective, the likelihood of further attacks by Wrongdoer becomes even lower than the pre-transactional likelihood. At the same time, the likelihood of wrongdoing by Victim remains the same. This too is

${ }^{83}$ Kant suggests that natural punishment should not be taken into account by legislatures (supra note 10) at para 331.

${ }^{84}$ Punishment is imposed on behalf of Victim's right for equality. Were Victim to have had the authority to punish, he would have been justified carrying out the punishment by himself. Even though punishment is imposed by the state, it is normatively attributable to Victim and so it affects the relationship between Wrongdoer and Victim. 
an upgrade in terms of Victim's boundaries with respect to Wrongdoer. Notably, deterrence is not the aim in and of itself, but a means to re-establish equality. ${ }^{85}$

Possibly, punishment also increases Victim's capability to formulate an independent self-identity in her relationship with Wrongdoer in another way. As demonstrated, punishment, and especially public condemnation, involves a reduction of Wrongdoer's robustness or authenticated separateness with respect to everyone else including Victim. Thus, it changes the meaning of Wrongdoer's intrusion for Victim's formation of independent self-identity. The intrusion remains, but it is now distanced from Victim - it belongs to a different reality, to the different people they once were. Punishment necessarily loosens the grip of Wrongdoer's past intrusion which allows Victim to authenticate her separateness with respect to Wrongdoer.

Since Victim's position is upgraded by the mere act of punishing Wrongdoer, the inequality between the two is diminished, and there is no need for a physical punishment that is as severe as the original crime.

Fourth, even if an argument for equality could prima facie justify "an eye for an eye”, such punishment would not be justified all things considered, at least where there is a risk of the state abusing its authority to punish.

Fifth, personhood has two implications: the minimum implication (Wrongdoer and Victim are to have minimal boundaries) and the equality implication (Wrongdoer and Victim are to have equal boundaries). Even if "an eye for an eye” restored equality, it would do so at the price of reducing Wrongdoer's boundaries, much like Victim, way below the minimum. Under such circumstances, full adherence to the claim of equality would not set humanity as the ultimate end. Rather, it would reflect a formal, almost technical understanding of equality, and as such it would not be justifiable. A justifiable response to intrusive wrongdoing would give some weight to the claim of equal value and some weight to the claim of minimal boundaries, thus imposing an intrusion that is milder than the original attack.

\section{(V) Moving Beyond the Paradigmatic Case}

Up to this point, this article has discussed what may be termed "simple cases" or "core cases". In analyzing attacks against life, body, or will, the concept of intrusion seems intuitive and plausible enough. Even attacks against property can be understood as intrusions under certain accounts of personal boundaries. ${ }^{86}$ But there are many other cases where the concept of intrusion of boundaries seems, at first sight, less

${ }^{85}$ Compare with Tadros' argument regarding the duty to carry a burden of general deterrence (Tadros, supra note 36).

${ }^{86}$ Dan-Cohen, supra note 38. 
helpful. These include mainly cases of endangerment, where the intrusion has not yet taken place; attacks against the public or the state, where no individual person is intruded upon; and cases involving non-deliberate conduct, where there is no attack on anyone's boundaries. Can the inequality of boundaries account justify punishment in such cases as well? In other words, does it provide a sufficient and necessary justification for the imposition of punishment? And if so, what does this concept imply in terms of actus reus and mens rea?

\section{Endangerment}

Many criminal prohibitions cover cases of mere risk creation. The risk can be concrete (a specific person is put in danger) or abstract, such as the risk posed by possession of weapons, ${ }^{87}$ dangerous operation of motor vehicles, ${ }^{88}$ and various terror offences such as financing terrorism ${ }^{89}$ or participation in the activity of a terrorist group. ${ }^{90}$ The justification for punishing risk-creation is a logical extension of the justification for punishing intrusion. Offences of endangerment are actually types of "remote harm offences"91 (in the proposed conceptualization: remote intrusion offences), and can be justified on similar lines. Wrongdoer, who endangers the boundaries of others, creates inequality between himself and the others, as his boundaries are more secure than those of the other. Where the risk is abstract, this other may be a (yet unknown) individual victim or victims. Alternatively, this other may be everyone, or all the members of the community. Everyone's abstract immunity from intrusion by Wrongdoer is reduced by dangerous conduct, while Wrongdoer's immunity from intrusion by others remains intact. Thus, Wrongdoer has an obligation to re-equate her relative position with respect to all others.

\section{Offences against the State or the Public}

The more troubling cases are those of offences against the state or the public, such as treason, ${ }^{92}$ unlawful drilling, ${ }^{93}$ offences against the administration of law, ${ }^{94}$ tax

${ }^{87}$ Criminal Code, RSC 1985, c C-46 s 88.

${ }^{88}$ Criminal Code, RSC 1985, c C-46 s 249.

${ }^{89}$ Criminal Code, RSC 1985, c C-46 s 83.02.

${ }^{90}$ Criminal Code, RSC 1985, c C-46 s 83.18.

${ }^{91}$ See Andrew von Hirsch, “Extending the Harm Principle: 'Remote' Harms and Fair Imputation” in AP Simester \& ATH Smith, eds, Harm and Culpability (Oxford:

Oxford University Press, 1996) at 259.

${ }^{92}$ Criminal Code RSC 1985, c C-46 s 46.

${ }^{93}$ Criminal Code RSC 1985, c C-46 s 70.

${ }^{94}$ Criminal Code RSC 1985, c C-46 ss 118-49. 
offences, ${ }^{95}$ or environmental offences. ${ }^{96}$ When it comes to such offences, intrusion of an individual's boundaries is very remote, to the point that it seems utterly irrelevant (think of tax evasion or pollution).

This is where the pursuit of the good enters the picture. Here as well, the pursuit of the good does not provide a direct justification for punishment, but in this specific context it does play a role in the construction of such a justification. The key for correct conceptualization of offences against the public or the state is the familiar idea of cooperation in fostering conditions for pursuit of the good. All these offences impose a demand for such cooperation: we are all required by law to cooperate in maintaining the state and its agencies that in turn help make our lives better; we are all required to cooperate to ensure efficient use of public goods. Cooperation is required not because it allows persons to maintain constituent boundaries, but because it improves people's lives; it ensures that they are best able to pursue the good.

Nonetheless, a legal demand for cooperation aimed at ensuring the good is not an easy or self-justifying thing. For example, compare a demand to pay taxes or separate waste for recycling with a demand not to kill or commit a physical assault. It is obvious to all that one must not kill or physically assault. Our boundaries are not transgressed when the law imposes such demands: these demands allow personhood, and a demand cannot both play a role in the constitution of personhood and transgress personhood at the same time. On the other hand, it is not clear to everyone that they must separate waste or pay taxes as required by law. Such demands do not play a role in the constitution of personhood, and their imposition by law does transgress our boundaries. It is an imposition of one actual will upon another, or a violation of property, as the case may be. Non-cooperation in pursuit of the good is, a priori, within the realm of non-interference, ${ }^{97}$ so when the state demands that we cooperate, it intrudes upon our boundaries. To be legitimate, such intrusion must accord with the preservation of minimal and equal boundaries for all.

95 Income Tax Act RSC 1985, c 1 (5th Supp) s 238.

${ }^{96}$ Offences according to Part 8 of the Canada Shipping Act, 2001, SC 2001, c 26 ss 165-84; Some of these offences, which may be characterized as are "non-attacks" consisting of non-deliberate conduct (for example, those carrying absolute liability), will be discussed in the next subsection.

\footnotetext{
${ }^{97}$ For this reason, a person who profits from his neighbour's landscaping is not required to share his profits with his neighbour. Had the state demanded that he would, this would have transgressed his boundaries. The question whether or not such a demand is legitimate is one of distributive justice and the limits of state action. I shall not discuss it at length here. A possible route for solving it would be seeking areas of overlap between (authenticated) personhood and the capability to pursue the good. Only where there is such overlap will redistribution be legitimate.
} 
The state is no one but all the other citizens who, in turn, allow us to transgress their boundaries symmetrically (they, too, pay tax and separate waste). The non-cooperator, however, intrudes upon our boundaries without allowing us a symmetrical intrusion. Thus, the scope of her boundaries with respect to each of the rest of the citizens is asymmetrical; by not cooperating, she creates inequality between herself and any lawabiding citizen. And it is this inequality which justifies punishment.

We can now see more clearly the attraction as well as the failure of Herbert Morris' conceptualization of the criminal conflict. ${ }^{98}$ Morris analyses crime as the taking of an unfair share of liberty. The criminal "renounces a burden which others have voluntarily assumed and thus gains an advantage which others, who have restrained themselves, do not possess". ${ }^{99}$ This conceptualization is extremely beneficial in understanding cooperation offences. Citizens are free not to cooperate for the benefit of a better life or environment. Where such freedom exists, cooperators can be seen as foregoing a piece of freedom, and accordingly, in such cases, non-cooperators may be seen as seizing an unfair share of freedom. This conceptualization of crime resembles the proposed analysis of offences against the public, where the legal prohibition is conceived as (justifiably) transgressing the boundaries of law-abiding citizens. However, the very same conceptualization fails when it comes to "core offences". Citizens are not free to kill or physically assault, and accordingly law-abiding citizens do not forego any share of freedom when abiding the law. In such circumstances, Wrongdoer who kills or assaults cannot be seen as seizing an unfair share of freedom; his wrongdoing stems from a different source. ${ }^{100}$ To overcome this analytical failure requires an examination of the notion of intrusion, to demonstrate that the source of the wrongdoing is an asymmetrical trespass of the boundaries of Victim (for core offences) or the boundaries of fellow citizens (for cooperation offences) by Wrongdoer.

\section{Non-Deliberate Conduct}

The paradigmatic case, namely the case of a battered woman, clearly presents an attack on Victim's personhood. Criminal law, however, also captures conduct that does not constitute an out-front attack, as well as conduct that does not constitute an attack at all. Willful blindness and recklessness are subjective mental elements that can give rise to criminal liability, even though the actor's conduct does not reflect a

${ }^{98}$ Herbert Morris, “Persons and Punishment” (1968) 52 The Monist 475. [Morris].

${ }^{99} \mathrm{Ibid}$ at 477. Various authors have attempted developing the idea of unfair advantage introduced by Morris. See John Finnis, “The Restoration of Retributivism” (1972) 32 Analysis 131; George Sher, Desert (Princeton: Princeton University Press, 1987) at 69-90; Richard Burgh, “Do the Guilty Deserve Punishment?” (1982) 79 J Philosophy 193; Michael Davis, "Criminal Desert and Unfair Advantage: What's the Connection?” (1993) 12 Law \& Phil 133.

${ }^{100}$ RA Duff, Trials and Punishments (New York: Cambridge University Press, 1986) at 211-17. For other criticisms see Dolinko, supra note 6. 
clear decision to challenge Victim's boundaries. Negligence is a lower objective standard of fault that can also give rise to criminal liability, even though the actor's conduct does not challenge boundaries at all. Criminal law regularly covers conduct such as reckless arson ${ }^{101}$ or criminal negligence causing death or bodily harm. ${ }^{102}$ If Victim's boundaries are not challenged, how can punishment for such non-attacks be justified?

There are two possible routes for addressing such non-attacks. The first one regards non-attacks as violations of cooperation rules oriented to achieve the good. The duty to be careful, to respond to risks, and to take care and to stretch our mental capabilities in order to maintain the safety of others, is nothing but a duty to cooperate in making everyone's lives better. If this is so, then the justification for punishment in cases of willful blindness and recklessness is similar to that described with respect to offences against the state and the public. While Wrongdoer's conduct does not reflect a clear decision to challenge boundaries, it does reflect a lack of willingness to be as careful and alert as other law-abiding citizens. Wrongdoer does not allow the state to intrude upon his boundaries by imposing a duty to be alert and careful, while still enjoying the intrusion by the state of the boundaries of others who do allow for the imposition of such a duty. The resulting inequality justifies punishment.

If non-attacks are so analyzed, punishment for objective negligence cannot be justified. The objectively negligent actor does not demonstrate unwillingness to be subject to a duty to be careful and alert. In many cases this actor was as careful and alert as she could be, but she merely lacked the abilities to be as careful and alert as other "reasonable" actors. Under the proposed analysis, a thorough subjectivism regarding fault is required: absolute liability is illegitimate; and as for the concept of negligence, to be legitimate it must be "subjectivized": it must accommodate all the personal characteristics of the actor in order to determine whether she was capable of making the necessary mental effort to identify the risk, but nonetheless, failed to do so. ${ }^{103}$ Accordingly, offences based on purely objective standards without taking the actor's subjective capabilities into account, such as the Canadian offences of criminal negligence causing death or criminal negligence causing bodily harm, ${ }^{104}$ would be found unconstitutional.

Notwithstanding the above analysis, it must be admitted that non-attacks often reflects more than lack of concern for other's capability to pursue the good; they reflect lack of respect for other's basic constitutive boundaries, such as bodily boundaries or boundaries of the will. An alternative route for conceptualizing nonattacks relies on the notion of transgression or intrusion of boundaries. I suggest, first,

${ }^{101}$ Criminal Code, RSC 1985, c C-46 s 434.

102 Criminal Code, RSC 1985, c C-46 ss 220-21.

103 See George P Fletcher’s discussion in “The Theory of Criminal Negligence: A

Comparative Analysis” (1971) 119 U Pa L Rev 401.

${ }^{104}$ Criminal Code, RSC 1985, c C-46 ss 220-21. 
that intrusion implies a boundary-crossing which is not contingent and which can be properly attributed to Wrongdoer; and second, that intrusion does not imply any higher level of blameworthiness of Wrongdoer. Let us examine each of these premises in turn.

Intrusion and transgression are normative notions implying culpability. The branches of a tree do not "intrude" into one's house or "transgress" one's property. In the current context, intrusion of boundaries implies boundary-crossing which is normatively attributable to the intruder, rather than boundary-crossing which is a mere contingency for the actor, just as it is for the person whose boundaries are crossed. ${ }^{105}$ If the boundary-crossing is not properly attributable to the actor, then the moral aspect of the boundary remains intact. Moral premises are not violated by contingencies, only by actors. In such a situation, the socio-moral boundary is not intruded. Accordingly, magnitudes of value in the relationship are not affected, and there is no inequality in the relevant sense. Furthermore, even if it were assumed that contingent crossing of boundaries creates some type of morally relevant inequality, this inequality would be bad, but it would not be unjust. Much like the inequalities resulting from luck, this inequality is not created by violation of rights. Where the inequality is bad, but not unjust, the leveling-down objection to the imposition of punishment, which will be discussed in the section VI, has greater force than in other situations, and it can work to make punishment unjustifiable.

While intrusion of boundaries implies non-contingency, it does not imply any higher level of blameworthiness. As we saw, where the boundary-crossing is non-contingent for the actor, socio-moral boundaries are intruded; rights are violated; and the resulting inequality of these boundaries is unjust. For the boundary-crossing to be non-contingent, or attributable to Wrongdoer, it has to be identifiable with Wrongdoer, even if it is not fully endorsed by him. To satisfy this condition, it is enough that Wrongdoer was capable of extending his will to this boundary-crossing or distancing himself from it by avoiding the conduct, but failed to do so. The conduct becomes his own by his failure, and there is no need for any stronger form of identification such as the one constituted by knowledge or deliberation.

It follows that, while not an attack on boundaries, non-deliberate conduct can still constitute an intrusion or transgression of boundaries. In this analysis as well, recklessness and "subjective negligence” can be criminalized, while objective negligence remains outside the reach of criminal law. To demonstrate this, let us think of Victim who is taking a walk on a dark bike path while wearing dark cloths at night. Wrongdoer is cycling on the same path and makes every effort to be alert to possible risks such as pit holes and passing cars (she has her light on, she cycles slowly, wears light clothes, etc.), but she does not consider the possibility that a pedestrian might choose to take a walk on the bike path while wearing dark cloths. She cannot possibly

${ }^{105}$ Intrusion does not necessarily imply blameworthiness. There can be a justified intrusion. 
see Victim, and she ends up hitting him. It would make no sense to consider Wrongdoer an intruder. Wrongdoer could not have considered the possibility of boundary-crossing and so the accident is a mere contingency for her. The situation is different where Wrongdoer cycles on the pavement with no lights, even if Wrongdoer honestly believes that there are no pedestrians on the streets so late at night. Wrongdoer was capable of being more alert and conscious of the risk, but failed to make the required mental effort. Accordingly, Wrongdoer was "subjectively negligent”. She did not take the value of other people's safety seriously enough to merit her attention and mental efforts. In this case Victim can sensibly and justifiably accuse Wrongdoer of intruding upon his body. ${ }^{106}$ Once an intrusion has been identified, punishment can be justified as redress for the inequality of respective boundaries.

\section{(VI)The Leveling-Down Objection}

The above proposed account may seem, at first blush, to be vulnerable to the levelingdown objection. According to this objection, there can be nothing good about achieving equality by detracting from the better-off in a way that does not contribute to the worse off. ${ }^{107}$ Thus, there can be nothing good about bringing Wrongdoer down to the position in which she has placed Victim by way of punishing her.

The leveling-down objection has been discussed at length in the literature about equality. ${ }^{108}$ There are three responses to this objection in the context of punishment. First, the objection is usually raised in the context of distribution of the good. Claims about distribution of the good are not claims about human value. The better-off do not have a higher value than the worse-off just because they are better-off; and accordingly equalization of their positions is not equalization of human value. In these circumstances it is indeed hard to see the moral significance of equalization.

However, in the proposed account, inequality generated by a crime is inequality in the magnitude human value. Thus anyone who shares the assumption that equality in the value of persons is something to be preserved would have to accept that equalization of boundaries is morally required.

Second, the leveling-down objection is relevant, or at least forceful, where the inequality cannot be attributed to the better-off in any way (i.e., under a telic account of equality). Thus it seems strongest in the purely theoretical case where the better-off does not know of the inequality and cannot reasonably gain knowledge of it. The

${ }^{106}$ Compare with Brudner's discussion of mens rea, supra note 4, especially at 75-81.

${ }^{107}$ Parfit, supra note 4 at 211, Temkin, supra note 81 at 247-48.

${ }^{108}$ See, e.g., Parfit, supra note 4 at 210-11, 218-20; Andrew Mason, "Egalitarianism and the Levelling Down Objection” (2001) 61 Analysis 246; Thomas Cristiano \& Will Braynen, “Inequality, Injustice, and Levelling Down” (2008) 21 Ratio 392; Nils Holtug, "Egalitarianism and the Levelling Down Objection” (1998) 58 Analysis 166. 
leveling-down objection loses its convincing force in direct proportion to the degree the inequality that may be attributed to the better-off (i.e., under a deontic account of equality). ${ }^{109}$ In the case of a criminal intrusion, the inequality is fully and directly attributable to Wrongdoer, and is thus utterly wrong and unjust. In such a case, the leveling-down objection seems weak at best.

Third, the leveling-down objection does not seem to apply to the proposed theory of punishment at all. As we have seen, punishment is more than a downgrading of Wrongdoer's position. It is also an upgrading of Victim's position. Victim's boundaries with respect to Wrongdoer are given extra scope, replacing some of the scope lost by the transgression. Thus punishment should more accurately be described as detracting significantly from the better-off, and improving to some (perhaps moderate) extent the position of the worse-off; and this seems justifiable. ${ }^{110}$

\section{(VII) Criminal Intrusion and Other Relationships of Equality}

Criminal intrusion involves a wrongdoer, a victim, and what we may call "the rest of the world" (or other members of the community). This section briefly clarifies why, at leastwhen analyzing core crimes, the focus is on the bilateral relationship between Wrongdoer and Victim (referring to the state as acting on behalf of Victim), while neglecting other members of the community.

The other members of the community are a priori situated in a position of equality with respect to Wrongdoer. Arguably, while punishment diminishes the inequality between Wrongdoer and Victim, it creates an inequality between Wrongdoer and the other members of the community. Thus it would apparently seem unjustifiable. Let us examine this argument. Punishment is an alteration of Wrongdoer's position which is morally significant for two reasons. First, it creates a further one-time vulnerability of Wrongdoer to (the state on behalf of) Victim. Here, Wrongdoer's position is altered only with respect to (the state on behalf of) Victim, but not with respect to other members of the community. There is no inequality between Wrongdoer and other members of the community in this respect. Wrongdoer is no more vulnerable to other members of the community than they are vulnerable to her.

Second, punishment entails certain "byproducts" that do create inequalities between Wrongdoer and other members of the community. Mainly, punishment includes public condemnation; and public condemnation involves not only the state but also all

${ }^{109}$ Parfit, supra note 4 . Thus where the rich refuses to give a dime to her poor neighbor, it seems less objectionable to take the dime from her altogether to reduce the inequality between the two. The rich is aware of the inequality and does nothing to redress it, therefore becoming in some weak way (through omission) responsible for the inequality. The inequality becomes unjust.

110 To be sure, so analyzed punishment most accords with what Parfit calls the Priority View (or, in Temkin's terminology, Extended Humanitarianism); but it also accords with my egalitarian assumptions. 
other members of the community, thereby undermining the formation of self-identity not only with respect to Victim but also with respect to all other members of the community. In addition, punishment detracts from Wrongdoer's capability to pursue the good and from her well-being thereby making her worse-off in these respects than the other members of the community.

Although Wrongdoer is worse off than the rest of the world, this does not give rise for her to make a claim for equality. Claims for equality are valid where people are worse off contingently, through no conduct that is attributable to them. ${ }^{111}$ The inequality between punished Wrongdoer and the rest of the world is fairly attributable to Wrongdoer (through her blameworthy conduct). This inequality is not the product of arbitrary contingencies and accordingly the principle of equality does not require that it is redressed.

The rest of the world is also a priori situated in a relationship of equality with Victim. Is the rest of the world obliged to subject itself to intrusion or deprivation, so that equality with Victim is restored following the intrusion? Here as well, the intrusion does not create a vulnerability of Victim to anyone but Wrongdoer; thus it does not place Victim in a position of inequality of boundaries with respect to the rest of the world. Yet certain byproducts of the intrusion, namely the deprivations of the capability to pursue the good and of well-being, do create inequality in these respects. Ideally, this inequality is redressed when Wrongdoer compensates Victim. If she does not, this can give rise to certain duties which are then borne by the general public. These duties arise not only from a telic conception of equality, but also from justice. The general public who does nothing to attend to victims of crime becomes, by this omission, responsible for the inequality between members of the public and such victims.

\section{(VIII) Inequality of Respective Boundaries and Other Deontological Accounts}

The account I propose justifies punishment as redress for (unjust) inequality. As seen in section I, accounts that justify punishment by reference to standards of equality and justice have been put forth previously. While clearly distinct, all existing accounts share certain deontological presumptions. The proposed account is not different; it takes equality and justice as a priori grounded, and justifies punishment in reference thereto. Nevertheless, the proposed account may be distinguished from existing deontological theories, and is, hopefully, more convincing.

111 Temkin, supra note 81 at 13; Thomas Nagel, Equality and Partiality (New York: Oxford University Press, 1991) at 71 (discussing the position that 'what seems to be bad is not that people should be unequal in advantages or disadvantages generally, but that they should be unequal in the advantages or disadvantages for which they are not responsible'). 
Most of the existing theories seem to presume that human value cannot be diminished, and that this value requires maintaining certain rightful conditions allowing everyone to pursue the good fairly. ${ }^{112}$ This view has its roots in Kantian theory attaching human value to the inviolable capacity for rationality. However, if Wrongdoer has no real effect over Victim's personhood and value, it becomes unclear what is so wrong about intruding upon Victim (beyond contingent "phenomenological" deprivations from the good that can be redressed by compensation) or how punishment redresses the wrongness. These difficulties have been demonstrated in the discussion of Ripstein's theory in section I.

The inequality of respective boundaries account acknowledges that Wrongdoer can reduce the magnitude of Victim's value from personhood in the context of his relationship with Wrongdoer, though without affecting the infinity of this value. By acknowledging the (limited) constitutive power that persons have over one another, the proposed theory avoids the above-mentioned difficulties. It points to the moral significance of intrusions, namely the asymmetrical reduction in magnitude of infinite human value. This asymmetrical reduction of value symbolizes unequal moral status; it means that Wrongdoer has fewer reasons to form an attitude of admiration towards Victim than Victim does towards Wrongdoer; and most significantly, it alters Wrongdoer's reasons to cooperate in formation and authentication of Victim's minimal self-identity without altering Victim's respective reasons. This condition of inequality is significant from the point of view of a morality of right and wrong (i.e., significant in terms of reasons for behaving respectfully). The proposed theory further demonstrates how punishment directly answers for this (unjust) inequality, namely, by decreasing Wrongdoer's infinite human value and increasing Victim's infinite human value in the relationship.

As we saw in section I, Brudner's Hegelian analysis attempts to avoid certain of the familiar difficulties of deontological accounts in a similar manner. Building upon the idea of mutual recognition, Brudner leaves place for the dialogic community in the constitution of agents or rather in the satisfying confirmation of their self-worth. This allows for analyzing crime as the denial of mutual recognition, and then justifying punishment as a negation by the dialogic community of this denial, which vindicates mutual recognition thereby allowing for the worthwhile existence of agents. I suggest that Brudner's account ends up encountering the same familiar difficulties of deontological accounts as do others; and that even were such account to surmount the difficulties, it would entail the familiar costs of Hegelian theories.

Like other deontological accounts, Brudner's account does not succeed in showing that civil compensation is not a sufficient remedy for Wrongdoer's violation. Brudner argues that compensation settles the dispute between Wrongdoer and Victim, but it leaves intact Wrongdoer's challenge against mutual recognition, or against the

112 See Ripstein, supra note 8. Morris (supra note 98) also shares at least the first presumption. 
possibility of rights and the authority of Law. ${ }^{113}$ However, at the same time, Brudner argues that compensation actually affirms and actualizes mutual recognition. Brudner writes: "civil remedies... restore wrongdoer and victim to the normative position of mutual recognition... In that the wrongdoer puts his victim back to where he was, he recants to the victim the claim of superiority his action implied, while the victim gains the wrongdoer's recognition for the right violated.... [Wrongdoer] had no right to perform the action in the first place, and coercing him [to compensate victim] realizes the right his action challenged." 114 [emphasis added]. However, if compensation is actually recognition and realization of Victim's right, does it not at the same time affirm and actualize the principle of mutual recognition, the possibility of rights and the authority of Law? Brudner argues that crime denies Victim's right, and that the denial of Victim's right is also a denial of the possibility of rights. If denying Victim's right can be interpreted as a denial of the possibility of rights, why can the recognition of Victim's right through compensation not be interpreted as an affirmation and vindication of the possibility of rights? Perhaps Brudner does not regard compensation as an act of recognition after all, but only as an act taking the parties back to the status quo ante in financial (rather than normative) terms. But if this is so, it may be wondered what Brunder's abovementioned references to mutual recognition imply.

Brudner might further reply that the dialogic community must reason in response to culpable wrongdoing. Crime is a public argument that Wrongdoer makes, according to which it is possible to act outside the bounds of agency. Compensation is not a valid counter-argument, since it merely brings the parties back to the status quo ante without demonstrating why wrongdoing is irrational or unreasonable. Only the universalization of Wrongdoer's hypothetical imperative through punishment is a counter-argument that refutes her argument. ${ }^{115}$ Punishment demonstrates that wrongdoing has self-destructive implications and is therefore irrational.

However, it is arguable that punishment cannot refute Wrongdoer's statement. Wrongdoer's argument is significant because it is interpreted as the overall negation

113 See Brudner, supra note 4 at 39-40, 47.

${ }^{114}$ Brudner, supra note 4 at 37.

115 On page 46 Brudner (supra note 4) writes: "Neither compensation nor punitive damages suffices to invalidate the right-denying claim expressed by an intentional interference. Compensation adequately realizes P's right to choose his ends against S's mistaken claim that $\mathrm{P}$ is not a right bearer; but it fails to address the wider implication of S's intentional interference, namely, that (since P is an agent) there can be valid claims to act outside the bounds of mutual respect for agency. Moreover, to require only that $\mathrm{S}$ compensate $\mathrm{P}$ and that $\mathrm{S}$ disgorge his gain from the wrongful transaction merely restores $S$ to the status quo ante where he enjoyed a right to mutually respectful liberty; whereas his claim is just that the status quo ante is invalid.” 
of Right and of mutual recognition as Law, and thus as a threat to the community whose Law it is. It is not only a negation of a certain right under certain circumstances, but a negation of the possibility of rights, and thus also the negation of the law that constitutes the community. The counter-argument would be that this negation turns Wrongdoer into a non-agent with no rights whatsoever, thus eliminating him. It exposes Wrongdoer to destruction; and it is this absolute selfdestructiveness that makes crime irrational and immoral. Punishment, on the other hand, does not present this counter-argument. Punishment does not demonstrate that the negation of Right is truly and wholly self-destructive and thus not valid; it does not put Wrongdoer at risk of arbitrary violations which would destroy her agency altogether. Being qualified, punishment is the imposition of only a limited regression from the status quo ante. As such, it merely demonstrates that wrongdoing exposes Wrongdoer to a certain violation which she may or may not be willing to bear. Yet as we saw when discussing Ripstein's argument in section I, an argument that ultimately conceives punishment as a cost does not succeed.

The inequality of boundaries account, on the other hand, does not analyze crime and punishment as public arguments. Accordingly, there is no need to show that compensation does not vindicate the Law of the community. Instead, the inequality of boundaries account focuses on the relationship between the parties and on the bilateral restoration of equality.

It can further be noted that under Brudner's theory, agents depend on the (political) dialogic community for confirmation of self-worth; without such confirmation, Wrongdoer's opposite principle of lack of worth stands. ${ }^{116}$ This assumption is crucial for Brudner's theory. Only under this assumption is the negation of the wrong by the dialogic community through punishment justified: punishment allows the members of the community a satisfying confirmation of self-worth through recognition and actualization of Right. However, these assumptions assign a leading role to the political community in the constitution of agents living with a sense of self-worth; and this makes agency (and thus also the argument) fragile: Agency, or at least agency as something of real worth, depends on the existence of a fully or almost fully dialogic community. If not fully dialogic, it no longer represents the free common will and accordingly it loses its qualification as recognizer and its authority to recognize

116 Describing the relation between the community and agents, Brudner writes: "a satisfying confirmation of self-worth can issue only from a relation of mutual recognition between free and equal persons. The same reasoning applies to the relationship between a political community and an individual agent." Brudner, supra note 4 at 306. So it is not only the community that requires the agent's confirmation; the agent requires the community's confirmation of its agency and worth. Without it, the agent is not constituted as a real, actual agent as the principle of non-agency remains to stand. 
agency; ${ }^{117}$ but this loss of authority, in turn, brings about the tragic extinction of agency as something worthwhile.

In contrast, my proposed analysis "de-centralizes" the constitution of personhood. The self is not constituted by a single Whole (the community) which qualifies as recognizer, but by multiple others, where the effect of each on the self is limited to the particular relationship. The political community only backs up this constitutive process to the limited extent it is able to do so; as such it also fulfills the role of another constitutor. Accordingly, no one person or entity constitutes personhood and is capable of being destructive of personhood. Even in the absence of a fully dialogic community, personhood remains intact thanks to the plurality of persons, some of whom remain respectful of Victim's boundaries. It can be suggested that this is an advantage of the inequality of boundaries theory: it proposes that personhood is less fragile than community-based theories would seem to suggest.

\section{(IX) Conclusion}

This article is an attempt to draft a justification for punishment based on the principle of equality, drawing upon Kantian ideas and their subsequent interpretations and development. The task is not an easy one: punishment has always been difficult to justify; and Kantian ideas regarding punishment are unpopular, in particular due to their alleged association with brutality. I have endeavored to reinterpret these ideas, to show that, where appropriately constructed, the principle of equality not only provides a solid basis for punishment, but also limits its extent.

In line with many liberal theories, my proposed approach is strongly particularized: its subjects are viewed as specific individuals rather than faceless institutions or the nebulous concept of community.

Nonetheless, this approach departs from Kantian metaphysics as it conceives of the individual as a unique self that is constituted in cooperation with others, in the context of the greater political community.

117 See Brudner's discussion, supra note 4 at 306-07. 